\title{
Hereditary multiple exostoses - a rare case
}

\author{
Shivaprakash N. C ${ }^{1}$, Naveen K. $\mathrm{S}^{2}$, Sowmya $\mathrm{S}^{3}$ \\ ${ }^{1}$ Dr. Shivaprakash. N.C, Professor and HOD, ${ }^{2}$ Dr Naveen K.S, Postgraduate, ${ }^{3}$ Dr. Sowmya S, Postgraduate, all authors \\ are affiliated with Department of Pediatrics, Adichunchunagiri Institute of Medical Sciences, B.G. Nagara Mandya \\ District, Karnataka, India.
}

Address for Correspondence: Dr. Naveen. K.S, Postgraduate in Pediatrics. Adichunchunagiri Institute of Medical Sciences, BG Nagara Mandya District, Karnataka, Email- id:naveen.ks29@yahoo.co.in

\begin{abstract}
Hereditary Multiple Exostoses (HME) is a genetically transmitted bone dysplasia that is inherited in an autosomal dominant manner. It usually presents after the age of two years as multiple bony growths on the appendicular skeleton. It is a rare condition with incidence of $0.9-2 / 1,00,00$ with few reported cases. We are hereby reporting an 8 year old boy with typical clinical and radiological features of Hereditary Multiple Exostoses (HME) in our hospital.
\end{abstract}

Keywords: Hereditary, Multiple, Exostoses, Autosomal Dominant, Deformity

\section{Introduction}

Hereditary Multiple Exostoses (HME or MHE) is also known as Diaphyseal Aclasis. This term is introduced by Keith [1]. In Multiple Exostosis there will be failure of bone remodeling and excess of metaphysis which is not resorbed but forms irregular cartilage capped exostosis.

The long bones of the lower limbs, arms, fingers, toes are commonly affected. Face and skull are unaffected. Exostoses grows with the child's age. It is the most common bone tumor seen in children [2-3].
It causes asymmetrical retardation of longitudinal bone growth with subsequent deformity and discrepancy in limb-length. Malignant transformation is in order of 5\% of all cases [4].

The clinical presentation may be in three stages. In the first stage, child presents with multiple lumps at the end of the long bones without any significant symptoms i.e., pain or deformity, second stage will presents with multiple lumps associated with pain or deformity and the third stage will have features of multiple lumps, pain and multiple deformities [5].

\section{Case Report}

A 8 year old boy born to a non consanguinous married couple brought with complaints of multiple swelling over both lower limbs and right upper limb since 4 years. Swelling associated with pain since 15 days over the left knee.

No change in skin colour or ulceration over the swelling. No history of trauma. No history of weight loss, headaches, anorexia, bone pain, jaundice, cough or breathlessness, abdominal swelling or any other constitutional symptom. There is history of similar complaints in the family. Father, paternal uncle and paternal grandfather have similar complaints.On examination child was conscious, oriented. Vitals were within normal limits. On systemic examination no abnormality detected. On local examination, the swelling over the left knee and right lower limb was measuring about $4 \mathrm{x} 5 \mathrm{~cm}$ (both), tender, no change in colour of overlying or surrounding skin, hard in consistency, immobile, skin over the swelling was pinchable, transillumination was negative. [Fig.1] There was, no loss of distal neurovascular function. Other swelling over right measuring about $2 \times 3 \mathrm{~cm}$, nontender, no redness, hard in consistency and fixed, skin over the swelling pinchable, transillumination negative. [fig 2] There were no limb length discrepancies.

Manuscript received: $30^{\text {th }}$ January 2017

Reviewed: $6^{\text {th }}$ February 2017

Author Corrected: $15^{\text {th }}$ February 2017

Accepted for Publication: 21 ${ }^{\text {st }}$ February 2017 
Blood investigations were within normal limits. X-ray Radiograph of right knee [fig 3] showed bony out-growths in the distal end of femur, growing away from the epiphysis. Radiograph of right hand showed bony outgrowth in the proximal humerus [fig 4].

A diagnosis of Hereditary Multiple Exostoses was made. Patient was started on NSAID's for pain. Parents were counseled on natural history of the disease and the prognosis associated with this condition. He is presently on follow up every 3 months.

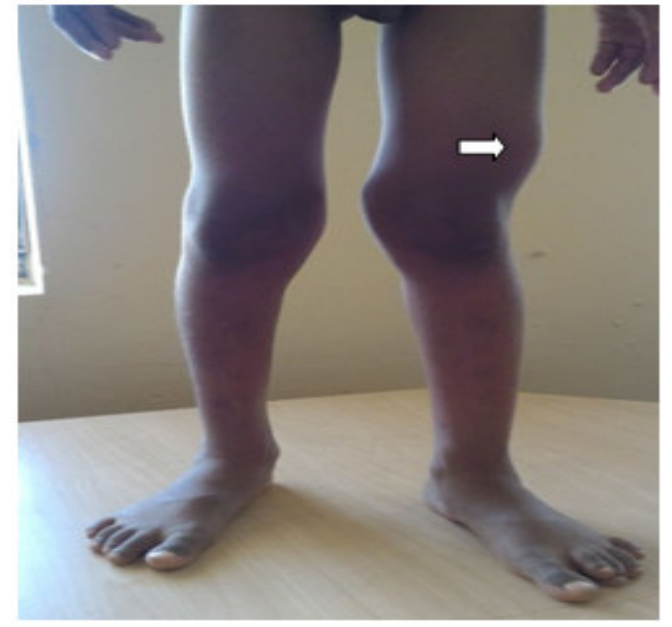

Fig-1: Swelling of the lower end of left femur

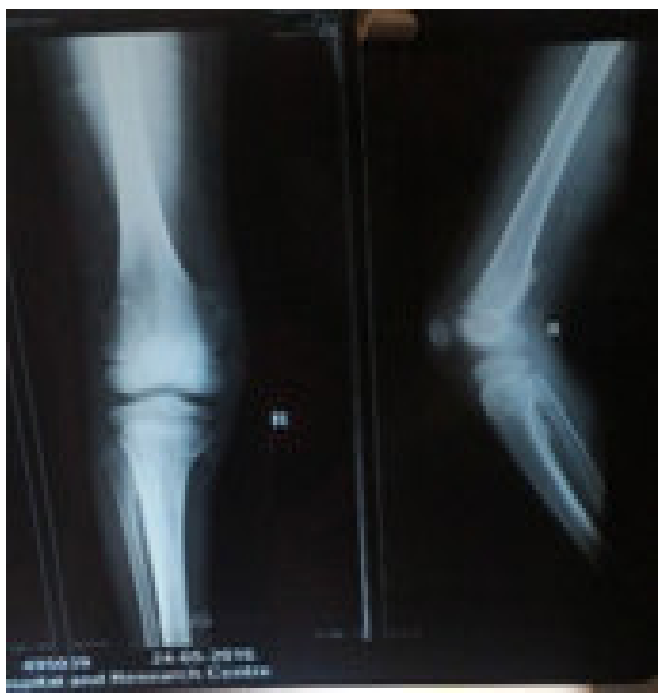

Fig-3: Xray shows bony out-growths in the distal end of femur, growing away from the epiphysis

\section{Discussion}

Hereditary Multiple Exostosis is characterized by the growth of cartilage-capped benign bone tumours around areas of active bone growth, particularly the metaphysis of the long bones. Typically five or six exostoses are found in upper and lower limbs. Most common locations are: Distal femur (70\%), Proximal tibia (70\%),

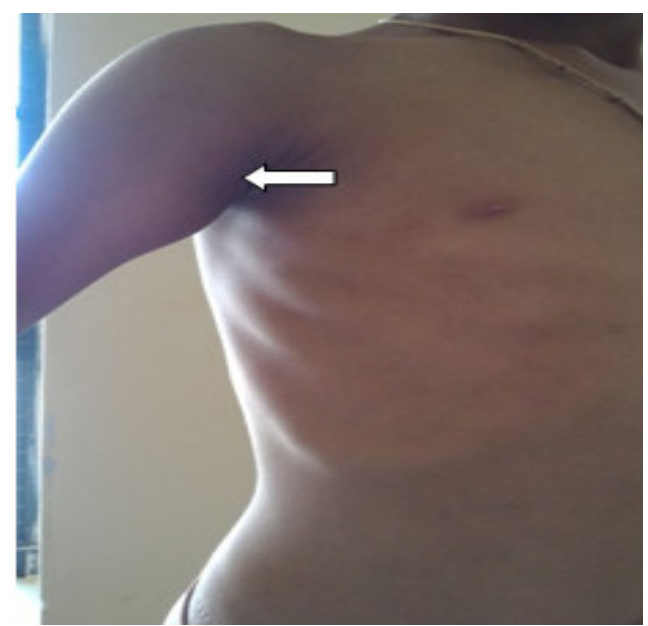

Fig-2: Swelling of the upper end left humerus

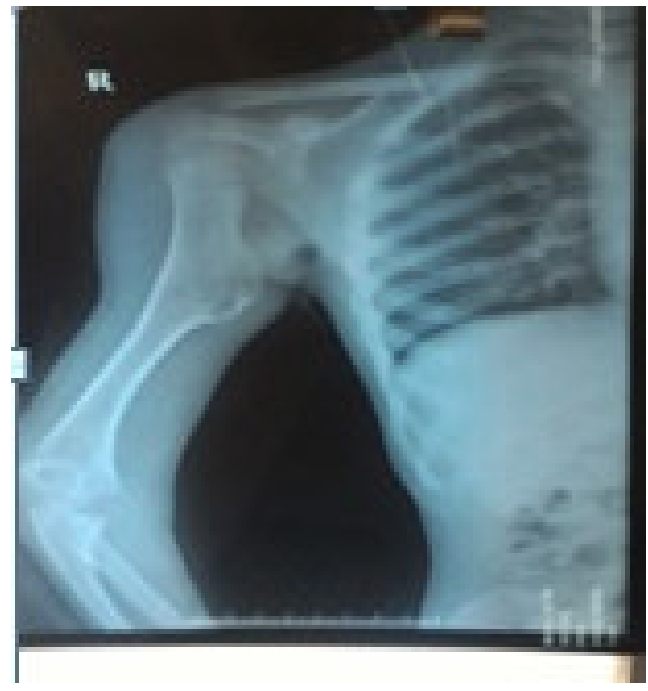

Fig-4: Xray of right hand showed bony outgrowth in the proximal humerus

Humerus (50\%), Proximal fibula (30\%)[6]. A diagnosis of can be made when radiologically at least two osteochondromas of the juxta-epiphyseal region of long bones are observed. In the majority of patients a positive family history and/or mutation in one of the EXT genes can be detected [7,8]. 
The prevalence of HME is estimated at 1:50,000 persons within the general population and seems to be higher in males (male-to-female ratio 1.5:1) [7, 9]. Approximately $62 \%$ of the patients with multiple osteochondromas have a positive family history $[3,7]$. Two genes, EXT1 and EXT2 located respectively at 8q24 and 11p11-p12, have been isolated to cause HME [10]. Additional linkage to chromosome 19p has been found, suggesting the existence of an EXT3-gene [11]. Malignant transformation of a benign osteochondroma to a chondrosarcoma or other sarcoma is another complication of HME. Unusual increase in size with pain in a previously symptomless exostosis may be suggestive of malignant change. Rarely, nerve compression can be the presenting complaint [12]. The reported rate of transformation ranges from as low as $0.57 \%$ to as high as $8.3 \%$ of people with HME [13]. Management of this condition depends on the presentation. Usually no treatment is required but if there are complications then surgical excision may be required. However,surgical interventions like corrective osteotomy, epiphyseodesis, excision, limb lengthening is indicated when the exostoses exhibit pressure symptoms, cause deformity or undergo malignant transformation [14].

\section{Conclusion}

Early diagnosis will helps in preventing the complications associated with this condition. The treatment of non-complicated HME is watchful waiting, and regular follow up with the aim of intervening surgically when any complications arise.

Funding: Nil, Conflict of interest: None initiated, Perission from IRB: Yes

\section{References}

1. John Ebnezar .Textbook of Orthopedics. $4^{\text {th }}$ ed. Jaypee Brothers Medical Publishers Ltd; 2013: 87-88.

2. Dahlin DC, Unni KK.Bone Tumors: General aspects and data on 11, 087 cases. 5th Ed. Philadelphia: Lippincott-Raven; 1996. P. 11-23.

3. Schmale GA, Conrad EU 3rd, Raskind WH. The natural history of hereditary multiple exostoses. J Bone Joint Surg Am. 1994 Jul;76(7):986-92.
4. Pannier S, Legeai-Mallet L. Hereditary multiple exostoses and enchondromatosis. Best Pract Res Clin Rheumatol. 2008 Mar;22(1):45-54. doi: 10.1016/j.berh. 2007.12.004.

5.Hennekam RC. Hereditary multiple exostoses. J Med Genet. 1991 Apr;28(4):262-6.

6. Turek's orthopaedics principles and their application. 6th ed. Philadelphia: Lippincott Williams \& Wilkins. 2005. p. 263.

7. Legeai-Mallet L, Munnich A, Maroteaux P, Le Merrer M. Incomplete penetrance and expressivity skewing in hereditary multiple exostoses. Clin Genet. 1997 Jul; 52(1):12-6.

8. Bovée G, Hogendoorn PW. Multiple osteochondromas. World Health Organization classification of tumours. Pathology and genetics of tumours of soft tissue and bone. Edited by: Fletcher CDM, Unni KK and Mertens F. IARC Press.Lyon 2002;360-62.

9. Wicklund CL, Pauli RM, Johnston D, Hecht JT. Natural history study of hereditary multiple exostoses. Am J Med Genet. 1995 Jan 2;55(1):43-6.

10. Cook A, Raskind W, Blanton SH, Pauli RM, Gregg RG, Francomano CA, Puffenberger E, Conrad EU, Schmale G, Schellenberg G, et al.Genetic heterogeneity in families with hereditary multiple exostoses. Am J Hum Genet. 1993 Jul;53(1):71-9.

11. Le Merrer M, Legeai-Mallet L, Jeannin PM, Horsthemke B, Schinzel A, Plauchu H, Toutain A, Achard F, Munnich A, Maroteaux P. A gene for hereditary multiple exostoses maps to chromosome 19p. Hum Mol Genet. 1994 May;3(5):717-22.

12. Paik NJ, Han TR, Lim SJ. Multiple peripheral nerve compressions related to malignantly transformed hereditary multiple exostoses. Muscle Nerve. 2000 Aug; 23 (8):1290-4.

13. Kivioja A, Ervasti H, Kinnunen J, Kaitila I, Wolf M, Böhling T. Chondrosarcoma in a family with multiple hereditary exostoses. J Bone Joint Surg Br. 2000 Mar;82(2):261-6.

14. Yinusa W, Owoola AM, Esin IA. Hereditary multiple exostoses: case report. Niger J Clin Pract. 2010 Jun;13(2):218-22.

\section{How to cite this article?}

Shivaprakash N. C, Naveen K. S, Sowmya S. Hereditary multiple exostoses - a rare case. J PediatrRes. 2017; 4(02):185187.doi:10.17511/ijpr.2017.i02.17. 